\section{Deconstructing reconstruction: the overlooked challenges of military occupation}

\section{Christopher Coyne}

$\mathrm{I}$

the post-Cold War period, the main threat to Western nations will not come from national superpower, but rather, from weak, failed and conflict-torn states and rogue groups within those states. As Robert Rotberg notes, "the rise and fall of nation-states is not new, but in a modern era when national states constitute the building blocks of world order, the violent disintegration and palpable weakness of selected African, Asian, Oceanic, and Latin American states threaten the very foundation of that system." The threats posed by these states are potentially formidable and cannot be ignored. In order to deal with the problems caused by weak, failed, and conflict-torn states, the United States has employed a number of overlapping strategies. These strategies have typically included some mix of delivering monetary and humanitarian aid, delivering military aid to certain groups or individuals, economic sanctions, and military occupation and reconstruction. My focus here is on the last of these strategies - the use of military occupiers to carry out reconstruction. With the ongoing struggles in Afghanistan and Iraq, as well as the threats posed by Iran and North Korea, the viability of military occupation and reconstruction as a means of generating fundamental change in weak, failed, and conflict-torn states is a central issue.

Reconstruction entails the use of military occupiers to establish peace while rebuilding, and in some cases building from scratch, both formal and informal institutions. ${ }^{2}$ More specifically, the reconstruction process involves the restoration of physical infrastructure and facilities, minimal social services, and structural reform in the political, economic, social, and security sectors. The end goal is the establishment of liberal democratic institutions, or at least the foundations of such institutions. ${ }^{3}$ The terms "reconstruction," "state building," "nation building," and "peacekeeping" are often used interchangeably. For my purpose, however, these terms capture overlapping but essentially different activities. When I use the term "reconstruction," I am referring to the process in its entirety, from the initial occupation through the exit of occupying forces, as well as the wide array of activities that occupiers undertake in the political, economic, and social arenas.

As the historical record indicates, the United States has not been overly successful in establishing liberal democratic institutions via military occupation in the post-Cold War period. ${ }^{4}$ Efforts in Somalia and Haiti failed to create sustainable change toward the desired end. While occupiers have established some semblance of peace in Bosnia and Kosovo, both remain heavily dependent on outside support in terms of governing personnel, security, and monetary aid. Moreover, the final political status of Kosovo has yet to be determined, which constrains any movement toward a self-sustaining liberal democratic entity. While the final outcomes of the efforts in Afghanistan and Iraq remain to be seen, the difficulties associated with these occupations are well documented.

The issues of military occupation and reconstruction are particularly messy and difficult. There are a large number of relevant and interacting variables that contain a large variety of historical experiences, cultures, and geo-political mechanisms Moreover, every occasion is highly unique which makes generalizations that much more difficult.

Recognizing these limitations, my goal is to explore two central, but often overlooked, issues that every occupation and reconstruction must face. I first focus on the "knowledge problem," which refers to the fact that policymakers, occupiers, and social scientists lack an understanding of how to establish the foundations of liberal democratic institutions where they do not already exist. I then turn to the "public choice problem," which focuses on the decisionmaking process. The political decisionmaking process within the country carrying out the occupation influences and shapes the nature of policies implemented during reconstruction efforts. Oftentimes, the incentives created by political institutions generate policies that run counter to the end goals of the broader reconstruction effort.

The knowledge problem

Policymakers, occupiers, and social scientists suffer from a fundamental knowledge problem when it comes to establishing liberal democratic institutions abroad. Stated differently, while there exists a firm understanding of what a successful reconstruction seeks to accomplish, much less is known about the appropriate steps to achieve this outcome. Most would agree that liberal democratic institutions are characterized by some mix of the rule of law, protection of individual, civil, and property rights, free and open elections, and the smooth transfer of power between elected officials. Despite general consensus on the end-goal, policymakers and occupiers have struggled to achieve success.

To further understand this knowledge problem, consider the ongoing debate in the social sciences regarding the conditions that are conducive to a liberal democratic order. Social scientists typically identify several key factors including experience with democracy, civil society, a minimal level of economic development, and the resulting middle class, ethnic and religious homogeneity, and some form of national identity as preconditions for liberal democracy. ${ }^{5}$ However, there is no consensus regarding the nature, magnitude, and mix of the factors necessary for sustainable liberal democracy.

Further, recent experience seems to call these standard assumptions into question. As Larry Diamond has recently indicated, scholars have spent decades attempting to understand the factors that contribute to stable democracies. However, Diamond notes that the wave of new democracies that arose between 1974-1994, a period wherein 
democracy spread to countries that lacked these conditions, "raised the prospect that democracy could emerge where the social scientists would least expect it." ${ }^{\prime 6}$ On the one hand, this fact can be viewed as a positive since it indicates that all countries have some democratic potential. On the other hand, this realization highlights the limited knowledge of scholars regarding the factors and causes of sustainable liberal democracy.

This fundamental knowledge problem has not stopped policymakers from using military occupation and reconstruction as a tool to attempt to bring about political, social, and economic change in weak, failed, and conflict-torn states. It has also led to an overemphasis on "controllable variables" such as troop levels, leadership strategy and planning, monetary and humanitarian aid, the timing of elections, and the exit of occupiers. This narrow focus can be seen in recent studies by the RAND Corporation that attempt to compare a number of controllable variables across reconstruction efforts in the hope of formulating "lessons learned." To be clear, it is not that these factors are unimportant, but rather to emphasize that a successful reconstruction is not simply a matter of exerting more effort. Instead, both controllable and uncontrollable variables (e.g., culture, belief systems, organizational forms, historical experiences, and other complementary institutions) are of the utmost importance.

Social scientists have long realized the importance of complementary informal institutions for the sustainability and functioning of formal liberal democratic institutions. For instance, Alexis de Tocqueville documented the importance of values and what he called the "art of association" for the nature of political, social, and economic institutions that existed in the United States. ${ }^{8}$ Tocqueville noted that this art of association, and the resulting social networks, are not the result of government design, but instead are the result of the ingenuity of self-reliant, entrepreneurial actors. Similarly, the economist F.A. Hayek noted the importance of informal beliefs and dispositions, "which in more fortunate countries have made constitutions work which did not explicitly state all that they presupposed, or which did not even exist in written form." $"$

The importance of belief systems and norms is also captured in the more recent economic literature that focuses on the idea of institutional "path dependence." ${ }^{\prime 10}$ This concept emphasizes that the way in which belief systems, rules, norms, and organizational forms developed in the past will constrain the feasible set of current and future choices. While these complementary institutions can change over time, social scientists and policymakers have a poor understanding of mechanisms that are effective in bringing about the desired changes.

In the context of reconstruction, the realization that historical experiences constrain the feasibility set in the present and future indicates that many weak, failed, and conflict-torn states may lack the prerequisites necessary for sustainable formal institutions. Further, policymakers and academics lack an understanding of how to change existing belief systems so that they may serve as a foundation for formal liberal democratic institutions. Where these complementary institutions are lacking, formal institutions imposed by occupiers will either be dysfunctional or fail to operate at all. ${ }^{11}$

The realization of the knowledge problem shifts the emphasis of reconstruction efforts from the overall level of "effort," typically measured by the level of controllable variables, to the importance of uncontrollable variables which are beyond the reach of policy, at least in the short-run. Ultimately, the effectiveness of controllable variables will be constrained by the belief systems, norms, rules, and organizational forms that evolved well before the military occupation and reconstruction effort. In other words, it is epistemologically impossible for occupiers to impose a set a set of formal institutions outside the existing context that has evolved over time. ${ }^{12}$

At its most fundamental level, reconstruction efforts entail the creation of a new set of rules that facilitate political, economic, and social interactions. The point being emphasized here is that these new rules will be binding only if context and customary practice dictates. The essence of the knowledge problem facing policymakers, occupiers, and social scientists is captured well by Douglass North when he notes, "We still do not know how to create polities that will put in place economic rules with correct incentives. We still have a very incomplete understanding of the complex institutional and technologically interdependent structure of political economies which is necessary to improving their performance." 13

It is critical for policymakers to recognize the contrast between the know what and the know how. While the end-goal of reconstruction efforts is clear, the means to achieve that goal are not. Increasing monetary and humanitarian aid, increasing troop strength and military funding, and holding elections will not, in themselves, lead to success in reconstructing weak, failed, and conflict-torn states. Indigenous informal institutions cannot simply be discarded and our knowledge and understanding of how to change the trajectory of existing belief structures, ideas, values, etc., is severely lacking. Recognizing the limits of our knowledge regarding the reconstruction of countries along liberal democratic lines should not be seen as a negative. Instead, recognizing the limits of our knowledge is necessary to framing a realistic policy agenda and avoiding the errors of constructivism.

The public choice problem

The knowledge problem focuses on the inability of policymakers and occupiers to possess the relevant understanding of how to construct liberal democratic institutions where they do not already exist. The actual implementation of policies is yet another challenge that is often overlooked when considering the viability of occupation and reconstruction efforts. Even if we assume that policymakers and occupiers possessed the relevant information to bring about the necessary institutional changes, would effective policies actually be implemented in practice? In order to answer this 
question, we need to consider the political decisionmaking process and the incentives facing those involved in that process. Public choice theory provides a means of doing so.

Public choice economics developed in the 1950s and evolved from the traditional field of public finance, which focuses on the study of government taxation and expenditure. ${ }^{14}$ The core principle of public choice theory is the symmetry of behavioral assumptions in the private and public spheres. Economists typically assume that private individuals act in a purposive manner, seeking to better their situation given their goals and constraints. Public choice theory extends this same assumption to actors in the public sector. In other words, it is assumed that those acting in the public sector, like private actors, pursue their goals to the best of their ability. Note that this does not mean that private and public actors are not "otherregarding," but rather it implies that both sets of actors tend to identify and pursue their own wants over those of others.

The symmetry of assumptions advanced by public choice theorists has major implications for the study of the public sector. No longer can it be assumed that those acting in the public sector are benevolently acting in the "public interest." Instead, while public actors may have some concern for others, their main motivation is the pursuit of their own well-being and the furthering of their own goals. Starting from the core assumption of behavioral symmetry, public choice theorists use the tools of economics to analyze the political decisionmaking process. Given that the public sector plays a major role in reconstruction efforts, public choice theory can offer insight into the overall process.

\section{The public choice model}

The model of politics and democracy developed by public choice theorists frames policies as the outcome of the interactions of four key groups - private voters, publicly elected officials, bureaucrats, and special interest groups. It is assumed that private voters and interest groups seek to maximize their utility and wealth, elected officials seek some mix of maximum votes, fame, power, and income, and bureaucrats seek to maximize their budget and job security.

Each group in the model seeks something possessed by one of the other groups. For example, voters and special interests want beneficial policies from elected officials who in turn want voter's support. Likewise, bureaucrats seek to increase their budget which is influenced by elected officials while elected officials seek goods and services from bureaucrats for their constituents. The interaction of these groups influences the nature of a wide array of policies including those associated with occupation and reconstruction.

For instance, voters and interest groups will seek to influence the policies enacted by elected officials and will support reconstructions if they perceive those efforts as furthering their own goals. Likewise, bureaucrats will seek to influence reconstruction efforts to pursue their goals of budget maximization and job security. Due to the incentives created by political institutions, the political decisionmaking process will often produce policies which fail to align with the broader aims of reconstruction efforts. Briefly considering each of the four groups will further illustrate this point.

Elected officials

A central insight from public choice theory is that the decisions of elected politicians are often shortsighted in nature. ${ }^{15}$ For those elected officials that are constrained by a term limit, the main focus is on obtaining the benefits during their time in office, even if these shorter-term benefits entail great costs that will be incurred in future periods. This is due to the fact that elected officials do not have to incur these costs if they occur after they have left office. In the context of reconstruction, elected officials will often consider the benefits and costs that accrue to them during their tenure, while neglecting those that occur after their tenure has ended. This can potentially produce ineffective policies that have long-lasting costs.

Elected officials face other perverse incentives as well. For instance, elected officials typically allocate resources to programs and activities that are readily observable to the average voter. This is precisely what one observes with attention being paid to the controllable variables in reconstruction - how much money and aid is delivered, how many building are constructed, the holding of elections, and an exit strategy. As discussed above, the effectiveness of these variables is directly constrained by complementary institutions which are beyond the control of elected officials. Nonetheless, these are easily measurable variables to signal "progress" to voters at home. The result is policies that have the potential to achieve visible and measurable outcomes instead of generating sustainable success.

\section{Voters}

In order to explain public opinion toward foreign interventions, social scientists have developed the "casualty hypothesis." In its simplest form, the casualty hypothesis indicates that there is an inverse relationship between the number of casualties and public support for the intervention. ${ }^{16}$ Stated differently, this theory indicates that as the number of American deaths increases, support for the intervention decreases. ${ }^{17}$ The political scientist John Mueller has applied the casualty hypothesis to a number of U.S. interventions, including the Korean and Vietnam wars, the intervention in Somalia, and the current intervention in Iraq, and it is his contention that the casualty hypothesis does in fact hold. ${ }^{18}$

The casualty hypothesis offers insight into what Niall Ferguson has called America's "attention deficit" toward foreign interventions. ${ }^{19}$ It is Ferguson's contention that a main reason that past U.S. efforts at reconstruction have met with failure is that the United States has refused to occupy countries for a sufficient period 
of time. The casualty hypothesis provides insight into why this is the case. When voters become dissatisfied with loss of U.S. troops, their support for the intervention shifts and elected officials feel pressure to respond accordingly.

Another important insight from public choice theory is that individual voters face an incentive to remain "rationally ignorant," meaning that they are largely uninformed of the specific choices and policies of political actors. The underlying logic is that each vote counts very little because it is unlikely that any one vote will influence the outcome of an election. Because there are positive costs associated with obtaining information regarding candidates and policies and the benefit of obtaining that information is small, given the lack of influence of a vote, voters typically remain uninformed of the particulars of policies. This logic explains why few voters know the specific details of candidates' voting records and the specifics of policies adopted. Instead, voters rely on general characteristics and outcomes - such as casualties as per the casualty hypothesis.

In the context of reconstruction, voters know in the broadest sense that a reconstruction effort is taking place but will fail to be informed regarding particulars of the effort - the allocation of resources, how long success may actually take, etc. Even if a longer term occupation may have significant benefits, individual voters will remain largely uninformed regarding the associated benefits and costs. As such, voters may demand policies from elected officials regarding reconstruction efforts that fail to align with the broader goals of reconstruction. In other words, there is no reason to believe that voters will demand the "best" policies given the goals of the reconstruction effort. This adds yet further insight into why we observe an American attention deficit disorder regarding occupations and why we should not expect the implementation of the best policies given the end goals.

\section{Special interests}

Whereas individual voters often lack the incentive to obtain detailed information, organized interests do have the incentive to obtain such information. Because of this, public choice theory emphasizes that special interest groups have major influence on the decisions of elected politicians and political outcomes in general. For example, the average U.S. voter is typically unaware of the amount and allocation of subsidies to the agriculture industry. However, those directly involved in the agriculture industry do have a direct interest in knowing the level of subsidies and how they are allocated. The reason this situation exists is that while the average voter garners little benefit from being informed regarding agricultural policy, the members of the agricultural industry receive significant benefits from such policies. As such, they have an incentive to be fully informed and to attempt to shape policy in their direction.

Due to the disconnect between uninformed voters and informed interest groups, the latter are able to influence political outcomes to concentrate the benefits of their lobbying expenses on the members of the group while dispersing the costs of the policies among uninformed voters. ${ }^{20}$ In terms of the previous example, those in the agriculture industry stand to gain significant benefits from influencing political outcomes while dispersing the costs among the rest of the uninformed tax paying voters. The outcome is that one should not expect the political process to produce policies that benefit the "public interest." The logic of special interest group politics influences a wide array of political decisions including those related to reconstruction efforts.

The role of special interest groups is evident in the current reconstruction efforts in Afghanistan and Iraq, especially when one looks at the contractors that have received funds from the U.S. government. Much has been made about the political connections of Halliburton and its construction subsidiary, Kellog, Brown, and Roo (KBR) which has received the largest total contract value to date in the Iraq reconstruction. These connections include both personal ties as well as significant monetary contributions that allowed Halliburton to influence the nature and magnitude of contracts in the post-war period. ${ }^{21}$ The political connections held by the top contractors go beyond Halliburton. For instance, The Center for Public Integrity has analyzed the political ties of other top contractors including Parsons Corporation, Fluor Corporation, and The Bechtel Group, Inc. ${ }^{22}$ The role that political connections and contributions play in securing reconstruction contracts is but one example of the role of interest groups in the broader reconstruction process. The important conclusion is that there is no reason to assume that the "best" provider of services will be chosen. Instead, many decisions associated with occupation and reconstruction will be based on political connections and pressures that may very well generate perverse outcomes given the goal of establishing the foundations of liberal democracy.

Bureaucrats

Bureaucrats hold non-elected positions in government. A wide variety of government agencies play a critical role in the reconstruction process. For example, the Department of State, Department of Commerce, Department of Defense, Army Corps of Engineers, Central Command, U.S. Agency for International Development, and Federal Business Opportunities, among other U.S. government agencies, are involved in the current reconstruction efforts in Iraq and Afghanistan. Because bureaucrats play a significant role in reconstruction efforts, it is important to consider the incentives they face.

Private markets and political institutions provide very different sets of incentives. Those acting in private markets are subject to market forces and act in an environment characterized by private property, prices, and profit and loss. Satisfying consumer wants generates a profit, while the failure to do so results in a loss. In contrast, public decisionmakers utilize the property of others (i.e., taxpayers), and are not subject to profit and loss like private businesses. Absent the profit motive, political criteria and pressures drive the allocation of resources in the public sector. 
For instance, government agencies receive a budget from elected officials and attempt to influence legislators to increase their budget. As already discussed, legislators respond to the demands of voters and special interests, and the activities demanded by these groups are typically executed by government agencies and bureaus staffed and operated by bureaucrats. As such, the relationship between legislators and bureaucrats is central to political outcomes.

Within this context, bureaucrats from different agencies compete with one another to secure a part of the limited government budget available at any point in time. Resources are allocated based on relationships with legislators and the stated budgetary needs of the agency. The incentives faced by bureaucrats include signaling to legislators and voters that their services are needed in greater amounts than currently exist. Because of this, bureaucrats will not only exhaust their entire appropriated budget, but also continually seek increases in their budget in order to increase the size of their agency. In the absence of the profit and loss mechanism, agencies are not subject to fiscal discipline and have little incentive to save and be cost effective. ${ }^{23}$

In the context of reconstruction, one observes the incentives facing bureaucracies generating perverse outcomes. For instance, there is often conflict between the aims and goals of different agencies each seeking to maximize its power and budget. This occurs despite the fact that the agencies are supposed to be working toward a common goal in the broader reconstruction effort. For example, David Phillips notes that during prewar planning for Iraq, "relations between the Office of the Secretary of Defense (OSD) and the State Department became increasingly acrimonious. U.S officials vied for control over the Iraq policy." 24 Similarly, Larry Diamond, who participated in the early stages of the Iraqi reconstruction, indicates that, "A number of U.S. government agencies had a variety of visions of how political authority would be reestablished in Iraq ... In the bitter, relentless infighting among U.S. government agencies in advance of the war, none of these preferences clearly prevailed." 25

Further, with little incentive to save and cut costs, one observes the misallocation and wasting of resources during reconstruction efforts. For example, one study of a $\$ 73$ million program to construct Afghani schools and clinics found a lack of coordination, poor planning, and the inability of government agencies to even know the locations of certain projects. ${ }^{26}$ Likewise, a recent audit of the reconstruction of Iraq showed millions of dollars of waste including \$36.4 million of unaccounted funds and millions more spent on an Olympic-size swimming pool and unnecessary VIP trailers. ${ }^{27}$ These are just a few examples of how the incentives facing bureaucrats will often generate perverse outcomes that run counter to the aims of reconstruction efforts.

\section{Conclusion}

I have considered two major challenges to any reconstruction effort. The first major challenge is the lack of knowledge of how to construct liberal democratic institutions where they do not already exist. The second major challenge is the political decisionmaking process and the fact that policymakers act within a set of institutions that tends to distort the policies driving the reconstruction process. Even if we assume that policymakers and occupiers possess the knowledge of how to construct libera institutions, there is good reason to believe that the political process will distort the actual implementation of the policies and directives based on that knowledge. Previous analyses of occupation and reconstruction have typically overlooked these challenges. Both policymakers and social scientists must recognize these constraints since any successful reconstruction effort will require finding viable solutions.

\section{Notes}

Christopher Coyne is an Assistant Professor of Economics at Hampden-Sydney College, in Hampden-Sydney, VA, the North American Editor of The Review of Austrian Economics, and a Research Fellow at the Mercatus Center, Arlington, VA. This article draws on some of the themes from his forthcoming book, After War: The Political Economy of Exporting Democracy, to be published by Stanford University Press in November 2007. He may be reached at ccoyne@hsc.edu.

1. Rotberg (2004, p. 1).

2. Institutions can be understood as the formal and informal rules governing human behavior and their enforcement. This enforcement can occur through the internalization of certain norms of behavior, the social pressure exerted on the individual by the group, or the power of third party enforcers who can utilize force on violators of the rules. Institutions can be traditional values or codified laws. However, as binding constraints on human action, they govern human affairs for good or bad, and as they change, so will the course of political, economic, and social development.

3. For the important difference between democracy and liberal democracy, see Zakaria (2003).

4. See for instance Coyne (2007); Payne (2006).

5. See Diamond, Linz, and Lipset (1995).

6. Diamond (2005, pp. 19-20).

7. Dobbins, et al. (2003); Dobbins, et al. (2005).

8. Tocqueville (1835/1839). 
9. Hayek (1979, pp. 107-108).

10. See North $(1990,2005)$.

11. Coyne (2005).

12. See Boettke (2001).

13. North (2005, p. 168).

14. For the classic text in public choice, see Buchanan and Tullock (1962). For more on the origins and development of public choice, see Buchanan (2003) and Tullock (1987).

15. Brennan and Buchanan (1985).

16. Luttwak $(1994 ; 1995 ; 1996)$ has developed and offered a defense of the casualty hypothesis.

17. One could broaden the casualty hypothesis to include severe injuries as well.

18. Mueller (1973, p. 60; 1994, p. 77; 1996; 2005).

19. Ferguson (2004, pp. 293-295).

20. Olson (1982).

21. See Briody (2004).

22. See The Center for the Public Integrity, "Windfalls of War" project. Project web site: http://www.publicintegrity.org/wow/.

23. See Tullock (1965) for the classic economic analysis of bureaucracy.

24. Phillips (2005, p. 7).

25. Diamond (2005, pp. 28-29).

26. Stephens and Ottaway (2005).

27. SIGIR (2007).

\section{References}

Boettke, P.J. 2001. "Why Culture Matters: Economics, Politics and the Imprint of History," in P.J. Boettke, ed. Calculation and Coordination. New York: Routledge.

Brennan, G. and J.M. Buchanan. 1985. The Reason of Rules: Constitutional Political Economy. Cambridge, MA: Cambridge University Press.

Briody, D. 2004. The Halliburton Agenda. New Jersey: Wiley \& Sons.

Buchanan, J.M. 2003. "Public Choice: The Origins and Development of a Research Program." Fairfax, VA: Center for Study of Public Choice. George Mason University.

Buchanan, J.M. and G. Tullock. 1962. The Calculus of Consent. Ann Arbor: University of Michigan Press.

Coyne, C. 2005. "The Institutional Prerequisites for Post-Conflict Reconstruction." Review of Austrian Economics, Vol. 18, No. 3/4, pp. 325-342.

Coyne, C. 2007. After War: The Political Economy of Exporting Democracy. Stanford, CA: Stanford University Press, forthcoming.

Diamond, L. 2005. Squandered Victory: The American Occupation and the Bungled Effort to Bring Democracy to Iraq. New York: Times Books.

Diamond, L., J.J. Linz, and S.M. Lipset. 1995. "Introduction: What Makes for Democracy?" in L. Diamond, J.J. Linz, and S.M. Lipset, eds. Politics in Developing Countries: Comparing Experiences with Democracy. 2nd ed. Boulder, CO: Lynne Rienner.

Dobbins, J., J.G. McGinn, K. Crane, S.G. Jones, R. Lal, A. Rathmell, R.M. Swanger, and A. Timilsina. 2003. America's Role in Nation-Building: From Germany to Iraq. Santa Monica, CA: RAND.

Dobbins, J., S.G. Jones, K. Crane, A. Rathmell, B. Steele, R. Teltschik, and A. Timilsina. 2005. The UN's Role in Nation-Building: From the Congo to Iraq. Santa Monica, CA: RAND.

Ferguson, N. 2004. Colossus: The Price of America's Empire. New York: Penguin. Hayek, F.A. 1979. Law, Legislation and Liberty. Volume III: The Political Order of a Free People. Chicago: The University of Chicago Press.

Luttwak, E.N.1994. "Where are the Great Powers? Home with the Kids." Foreign Affairs, Vol. 73, No. 4, pp. 23-28.

Luttwak, E.N. 1995. “Toward a Post-Heroic Warfare.” Foreign Affairs, Vol. 74, No 3, pp. 109-122.

Luttwak, E.N. 1996. “A Post-Heroic Military Policy.” Foreign Affairs, Vol. 75, No. 4, pp. 33-44.

Mueller, J.E. 1973. War, Presidents and Public Opinion. New York: Wiley \& Sons.

Mueller, J.E. 1994. Policy and Opinion in the Gulf War. Chicago: The University of Chicago Press.

Mueller, J.E. 1996. "Policy Principles for Unthreatened Wealth-Seekers.” Foreign 
Policy, Vol. 102, pp. 22-33.

Mueller, J.E. 2005. “The Iraq Syndrome.” Foreign Affairs, Vol. 84, No. 6, pp. 44-54.

North, D. 1990. Institutions, Institutional Change and Economic Performance. Cambridge, MA: Cambridge University Press.

North, D. 2005. Understanding the Process of Economic Change. Princeton, NJ: Princeton University Press.

Olson, M. 1982. The Rise and Decline of Nations: Economic Growth, Stagflation, and Social Rigidities. New Haven, CT: Yale University Press.

Payne, J.L. 2006. “Does Nation Building Work?” The Independent Review, Vol. X, No. 4, pp. 597-608.

Phillips, D.L. 2005. Losing Iraq: Inside the Postwar Reconstruction Fiasco. New York: Basic Books.

Rotberg, R.I. 2004. "The Failure and Collapse of Nation-States," in R.I. Rotberg, ed. When States Fail: Causes and Consequences. Princeton, NJ: Princeton University Press.

[SIGIR] Special Inspector General for Iraq Reconstruction. 2007. “January 30, 2007 Quarterly and Semiannual Report to Congress." Available at http://www.sigir.mil/reports/quarterlyreports/Jan07/Default.aspx

Stephens, J. and D.B. Ottaway. 2005. "A Rebuilding Plan Full of Cracks." The Washington Post. 20 November 2007, p. A01.

Tocqueville, A. de. 1835/1839 [1969]. Democracy in America. Edited by J.P. Mayer, translated by George Lawrence. New York: Doubleday \& Co.

Tullock, G. 1965 The Politics of Bureaucracy. Washington, DC: Public Affairs Press.

Tullock, G. 1987. "Public Choice," pp. 1040-1044 in The New Palgrave: A Dictionary of Economics. Vol. 3.

Zakaria, F. 2003. The Future of Freedom: Illiberal Democracy at Home and Abroad. New York: W.W. Norton. 